\title{
ASSOCIATION BETWEEN ADROPIN AND INTIMA-TO-MEDIA THICKNESS IN HYPERTENSIVE PATIENTS WITH TYPE 2 DIABETES
}

\author{
Boris Shelest \\ Department of Internal and Occupational Diseases, Kharkiv National Medical University, Kharkiv, Ukraine
}

\section{VEZA IZMEĐU ADROPINA I DEBLJINE SLOJA INTIMA-MEDIA KOD HIPERTENZIVNIH PACIJENATA SA DIJABETESOM TIP 2}

\author{
Boris Shelest \\ Katedra za interne i profesionalne bolesti, Harkov nacionalni medicinski univerzitet, Harkov, Ukrajina
}

\begin{abstract}
Objective. Hypertension (HTN) and diabetes mellitus type 2 (2TDM) are considered to be risk factors for atherosclerosis and cardiovascular diseases. Our study suggests that a hormone peptide, called adropin, is involved in the processes of atherosclerotic vessels' damage in hypertensive patients with T2DM and obesity. As inflammation also suggested being involved in atherosclerosis processes, we studied the IL6 concentration in enrolled patients. The goal was to estimate the links between atherosclerosis intensity and adropin concentration in patients with combination of HTN and 2TDM with obesity.
\end{abstract}

Methods. A group of hypertensive patients with 2TDM and obesity ( $n=99)$ was prospectively enrolled into the study. The serum IL-6 and adropin levels were measured by ELISA, and the atherosclerosis marker was carotid intima-media thickness. The patients were divided into the group 1 with atherosclerosis (the carotid intima media thicknessCIMT $\geq 0.9 \mathrm{~mm})(\mathrm{n}=69)$, and group 2 without atherosclerosis $(C I M T<0.9 \mathrm{~mm})(\mathrm{n}=30)$.

Results. IL-6 level was found to be significantly conversely correlated with serum adropin level only when analysed among all the enrolled subjects, including the control group $(r=-0,48, P<0.05)$, but not in the rest of groups. Patients with CIMT $\geq 0.9 \mathrm{~mm}$ had significantly decreased adropin concentration, and not significantly decreased IL-6 level, comparing with the patients with CIMT $<0.9 \mathrm{~mm}$. Receiver operating characteristic showed that adropin $\leq 1.80$ $\mathrm{ng} / \mathrm{ml}$ was the best cut-off point for differentiating patients with atherosclerosis from patients without atherosclerosis among hypertensive subjects with concomitant 2TDM and obesity (sensitivity $=76.67 \%$, specificity $=68.12 \%$ ).

Conclusion. A diminished serum adropin concentration was associated with increased atherosclerosis manifestation, as evidenced by a higher CIMT.

Key words: hypertension; peptide hormones; diabetes mellitus.

\section{INTRODUCTION}

The combination of arterial hypertension (HTN) and diabetes mellitus type 2 (2TDM) is characterized by a high increase in the incidence among the population all over the world. The course and prognosis of hypertension significantly deteriorated in the presence of concomitant

\section{SAŽETAK}

Cilj. Hipertenzija (HTN) i dijabetes melitus tip 2 (2TDM) smatraju se faktorima rizika za aterosklerozu $i$ kardiovaskularne bolesti. Naša studija pokazuje da je hormonski peptid, nazvan adropin, uključen u procese oštećenja aterosklerotskih krvnih sudova kod hipertenzivnih pacijenata sa T2DM i gojaznošcu. Kako je sugerisano da je inflamacija takođe uključena $u$ procese ateroskleroze, proučavali smo koncentraciju IL-6 kod uključenih pacijenata. Cilj je bio da se procene veze između intenziteta ateroskleroze $i$ koncentracije adropina kod pacijenata sa kombinacijom HTN i 2TDM sa gojaznošcu.

Metode. U studiju je prospektivno uključena grupa hipertenzivnih pacijenata sa 2TDM i gojaznošcu $(n=99)$. Nivoi IL-6 i adropina u serumu su mereni ELISA testom, a marker ateroskleroze je bio debljina sloja intima-medija kod karotide. Pacijenti su podeljeni u grupu 1 sa aterosklerozom (CIMT>0,9 mm) $(n=69)$, a grupa 2 bez ateroskleroze (CIMT $<0,9 \mathrm{~mm})(n=30)$.

Rezultati. Utvrđeno je da je nivo IL-6 značajno $u$ suprotnosti sa nivoom serumskog adropina samo kada se analizira među svim uključenim subjektima, uključujući $i$ kontrolnu grupu $(r=-0,48, P<0,05)$, ali ne $i$ u ostalim grupama. Pacijenti sa CIMT>0,9 mm su imali značajno smanjenu koncentraciju adropina, a nisu značajno smanjili nivo IL-6, u poređenju sa pacijentima sa CIMT <0,9 mm. Operativna karakteristika primaoca pokazala je da je adropin $\leq 1.80 \mathrm{ng} / \mathrm{ml}$ bio najbolja granična tačka za razlikovanje pacijenata sa aterosklerozom od pacijenata bez ateroskleroze kod hipertenzivnih subjekata sa konkomitantnom 2TDM $i$ gojaznosti (senzitivnost $=76,67 \%$, specifičnost $=68,12 \%$ ).

Zaključak. Smanjena koncentracija adropina u serumu bila je povezana sa povećanom manifestacijom ateroskleroze, o čemu svedoči viši CIMT.

Ključne reči: hipertenzija; peptidni hormoni; dijabetes melitus.

pathology - type 2 diabetes mellitus, the main causes of which are obesity, associated insulin resistance (IR) and dyslipidemia (1). The combined course of hypertension and 2TDM has a mutually aggravating pattern and it is associated with a high risk of microvascular complications and cardiovascular disease (CVD) development (2). 
Therefore, the search and study of new markers for the development of this combined pathology is one of the most important problems of modern health care. The recent studies of cardiovascular disease involve the evaluation and monitoring of biological markers that allow assessing the state of the cardiovascular system at an early stage and timely appointing adequate therapies or even preventing the development of complications.

It is known that such biological markers include adropin as well as other markers. Adropin is coupled to regulation of the endothelial function and might be the background for creating novel therapeutic opportunities of metabolic disorders associated with atherosclerosis (3). There is data that show participation of adropin in the mechanism of T2DM (4). It participates in the mechanism of raised adiposity, insulin resistance, and glucose and lipid metabolism (5). Therefore, adropin may play a role in the pathogenesis of target-organ deterioration in diabetic and hypertensive patients. The question of the adropin's predictive importance in worsening in patients with hypertension combined with 2TDM and obesity altogether remains not fully investigated.

The aim of our study was to determine the role of serum adropin in the progression of target organ damage, manifested as atherosclerotic damage of the vessels, in hypertensive patients combined with 2TDM and obesity.

\section{MATERIAL AND METHODS}

The ninety nine patients with HTN combined with 2TDM and obesity hospitalized at the therapeutic and cardio departments of Kharkov City Clinical Emergency and Urgent Hospital and Regional Kharkov Clinical Hospital (Kharkov, Ukraine) were successfully enrolled into the study. They were divided into 2 experimental groups accordingly to the level of atherosclerosis evaluated by the carotid intima media thickness (CIMT): $1^{\text {st }}$ group with CIMT $\geq 0.9 \mathrm{~mm} ; 2^{\text {nd }}$ group - CIMT $\leq 0.9 \mathrm{~mm}$. HTN patients were not under previous antihypertensive therapy. They used oral antihyperglycemic agents (biguanides or/and sulfonylurea), while insulin was not used. Control group consisted of 20 practically healthy persons without any signs of HTN, DM, and obesity. Diagnosis of HTN was based on Arterial Hypertension (Management of) ESC Clinical Practice Guidelines 2013, and Ukrainian national recommendations, and 2TDM diagnosis in accordance to World Diabetes Federation guidelines (IDF, 2011). Exclusion criteria were: other cardiovascular disease, myocardial infarction (MI) and stroke in anamnesis, acute inflammation, malignant tumor, renal failure (estimated GFR - glomerular filtration rate of $<60 \mathrm{~mL} / \mathrm{min}$ ), secondary HTN, ejection fraction $<45 \%$, chronic obstructive pulmonary disease, hepatic diseases, and alcohol abusers.

CIMT of the participants was calculated according to the guidelines of the ESC recommendation (6). It was performed in high-resolution B-mode regimen on ultrasound "Philips HD11XE" US frequency with 7.5 $\mathrm{MHz}$.

Determination of the level of glycated hemoglobin (HbAlc) was carried out by chromatographic method using the test system "Reagent" (Ukraine). The lipid metabolism was evaluated by the definition of total cholesterol (TC), high density lipoprotein cholesterol (HDLC) by triple-layer peroxides bridge method, by sets of Cholesterol Liquicolor, Human (Germany) reagents. The level of triglycerides (TG) is determined by CHODPAP method, sets of "Triglycerides GPO Human" (Germany). The level of creatinine was determined in blood serum by Popper method, GFR calculated by Cockroft-Gault formula. IL-6 was measured using ELISA on StatFax 2100 (USA) in accordance with the company instructions ("VectorBest", Russia).

Serum was obtained from blood samples by centrifugation and kept at $-80^{\circ} \mathrm{C}$ prior to analysis. Serum adropin levels were measured using an enzyme-linked immunosorbent assay kit (JRDUN Biotechnology Co., Ltd., CPR) according to the manufacturer's instructions, (coefficients of variations (CVs) for intra-assay: 5-7\%; $\mathrm{CVs}$ for interassay: $12-15 \%$; sensitivity: $0.3 \mathrm{ng} / \mathrm{mL}$, detection limit range: $0.01-100 \mathrm{ng} / \mathrm{mL}$ ).

The Institutional Bioethics Committee of Kharkiv National Medical University approved our study. All enrolled participants submitted a written informed consent. The investigation carried out with the principles outlined in the Declaration of Helsinki.

Data were assayed using Statistica 12.0 StatSoft, USA statistics package. Continuous variables were reported as mean $\pm \mathrm{SD}$ and categorical variables were reported as percentages and counts. Student's t-test was used for comparison of normally distributed variables and MannWhitney U test was used for non-normally distributed variables. ANOVA test was used to compare normally distributed variables between 2 or more groups and Kruskal-Wallis ANOVA in case on not normal distribution. Categorical variables were compared by $\chi 2$ test or Fisher's exact test, as appropriate. Pearson's correlation coefficients were used to assess links between continuous variables with normal distributed and Spearman correlation analysis was performed for nonnormal distribution and categorical variables. In all analyses, $p$ value of $<0.05$ was considered statistically significant. MedCalc program ver.18.2.1 trial version was used to make ROC-analyses.

\section{RESULTS}

Table 1 presents clinical characteristics of patients with HTN combined with 2TDM, divided in two experimental groups (group 1 - with increased CIMT $\geq 0.9 \mathrm{~mm}$, and group $2-$ with normal value of CIMT $<0.9 \mathrm{~mm}$ ), and controls. 
In terms of age, sex and smoking status the patients did not have significant differences between groups. The rest of indices had a statistical difference.

The patients with combined HTN and 2TDM in both groups had a significantly higher DBP and SBP than healthy controls, and had statistical difference between 1 and 2 groups (DBP: $102.53 \pm 6.17$; vs $98.70 \pm 6.60$; vs $82.15 \pm 4.96 \mathrm{mmHg} p<0.001 ;$ SBP: $172.8 \pm 6.46$ vs $164.41 \pm 10.51$ vs $132.35 \pm 6.05 \mathrm{mmHg}, \mathrm{P}<0.001)$.

There were significant differences in all observed parameters between experimental groups compared to healthy controls (BMI; HbAc1; TC, TG, HDL, IL-10, IL6, adropin). Such an index as LVEF (left ventricle ejection fraction \%) did not reveal significant differences between experimental group1 and group2 $(\mathrm{p}=0.0611)$; between group 1 (CIMT $\geq 0.9 \mathrm{~mm})$ and controls $(\mathrm{p}=0.0810)$; group 2 (CIMT $<0.9 \mathrm{~mm})$ and controls $(\mathrm{p}=1.000)$. GFR and LDL comparing between group 1 and control finalized in absence of statistical differences $(\mathrm{p}=0.0658, \mathrm{p}=0.4074$ respectively).

The subjects from group 2 (CIMT $<0.9 \mathrm{~mm}$ ) had significant differences in GFR with controls $(86.77 \pm$ 20.80 vs $99.07 \pm 4.58 \mathrm{~mL} / \mathrm{min} / 1.73 \mathrm{~m} 2, \mathrm{P}=0.0007$ ).

Obesity was presented only in the experimental subjects, but not in controls, and BMI was significantly different comparing experimental groups to the control $(p<0.0001)$ and among themselves $(p<0.0084)$.

CIMT values were significantly higher in both experimental groups than in controls $(\mathrm{p}<0.0001)$. Conversely, serum adropin level was lower in both main groups compared with controls $(1.48 \pm 0.66$ and $2.08 \pm 0.75$ vs $4.90 \pm 0.58 \mathrm{ng} / \mathrm{mL}, \mathrm{P}<0.001)$. It is important to emphasize, that serum adropin was significantly decreased in the group with enlarged CIMT $(\geq 0.9 \mathrm{~mm})$ compared to the patients with HTN and 2TDM who had normal values of $\operatorname{CIMT}(<0.9 \mathrm{~mm})(1.48 \pm 0.66$ vs $2.08 \pm 0.75, \mathrm{p}=0.0003)$.

Table 1. Clinical characteristics of the subjects enrolled into the study.

\begin{tabular}{|c|c|c|c|c|c|c|c|}
\hline \multirow[t]{2}{*}{ Parameter } & \multicolumn{2}{|c|}{ HTN with 2TDM and obesity } & \multirow[t]{2}{*}{ Control $n=20$} & \multicolumn{4}{|c|}{ P-level } \\
\hline & $\begin{array}{l}\text { Group } 1 \\
(\text { CIMT } \geq 0.9 \mathrm{~mm}) \\
\mathrm{n}=30\end{array}$ & $\begin{array}{l}\text { Group } 2 \\
(\text { CIMT <0.9), } \\
n=69\end{array}$ & & $\mathrm{P}^{*}$ & $\mathrm{P} \alpha$ & $\mathrm{P} \beta$ & $\mathrm{P} \delta$ \\
\hline Male/Female & $12(40 \%) / 18(60 \%)$ & $30(39 \%) / 39(61 \%)$ & $8(40 \%) / 12(60 \%)$ & 0.99 & 0.94 & 0.99 & 0.95 \\
\hline Age, year & $61.43 \pm 8.32$ & $63.35 \pm 9.01$ & $59.1 \pm 4.56$ & 0.98 & 0.99 & 0.88 & 0.89 \\
\hline $\begin{array}{l}\text { Current } \\
\text { smoking, n (\%) }\end{array}$ & 7 & 13 & 4 & 0.99 & 0.89 & 0.90 & 0.98 \\
\hline $\begin{array}{l}\text { HTN duration } \\
\text { (years) }\end{array}$ & $10.77 \pm 5.06$ & $11.42 \pm 4.77$ & - & $<0.01$ & 0.99 & $<0.01$ & $<0.01$ \\
\hline $\begin{array}{l}\text { 2TDM duration } \\
\text { (years) }\end{array}$ & $13.15 \pm 6.90$ & $13.19 \pm 6.85$ & - & $<0.01$ & 0.99 & $<0.01$ & $<0.01$ \\
\hline CIMT, mm & $0.984 \pm 0.08$ & $0.798 \pm 0.07$ & $0.617 \pm 0.08$ & $<0.01$ & $<0.01$ & $<0.01$ & $<0.01$ \\
\hline BMI $\left(\mathrm{kg} / \mathrm{m}^{2}\right)$ & $32.46 \pm 5.62$ & $30.77 \pm 4.99$ & $20.85 \pm 2.21$ & $<0.01$ & 0.01 & $<0.01$ & $<0.01$ \\
\hline $\mathrm{SBP}(\mathrm{mmHg})$ & $172.8 \pm 6.46$ & $164.41 \pm 10.51$ & $132.35 \pm 6.05$ & $<0.01$ & $<0.01$ & $<0.01$ & $<0.01$ \\
\hline DBP (mmHg) & $102.53 \pm 6.17$ & $98.70 \pm 6.60$ & $82.15 \pm 4.96$ & $<0.01$ & $<0.01$ & $<0.01$ & $<0.01$ \\
\hline LVEF, $(\%)$ & $52.7 \pm 11.72$ & $57.87 \pm 8.03$ & $59.05 \pm 3.59$ & 0.01 & 0.06 & 0.08 & 1.00 \\
\hline $\mathrm{HbA1C}(\%)$ & $9.51 \pm 1.15$ & $9.7 \pm 1.14$ & $5.62 \pm 0.29$ & $<0.01$ & 0.47 & $<0.01$ & $<0.01$ \\
\hline $\mathrm{TG}, \mathrm{mmol} / \mathrm{l}$ & $2.77 \pm 1.66$ & $2.17 \pm 0.88$ & $1.12 \pm 0.48$ & $<0.01$ & 0.12 & $<0.01$ & $<0.01$ \\
\hline $\mathrm{TC}, \mathrm{mmol} / \mathrm{l}$ & $6.43 \pm 1.22$ & $6.17 \pm 1.48$ & $5.05 \pm 0.43$ & $<0.01$ & 0.30 & $<0.01$ & $<0.01$ \\
\hline HDLC, $\mathrm{mmol} / \mathrm{l}$ & $1.20 \pm 0.27$ & $1.21 \pm 0.23$ & $1.86 \pm 0.43$ & $<0.01$ & 0.66 & $<0.01$ & $<0.01$ \\
\hline LDLC, mmol/1 & $4.57 \pm 1.10$ & $4.80 \pm 1.31$ & $3.86 \pm 0.84$ & $<0.01$ & 0.54 & 0.07 & 0,01 \\
\hline $\begin{array}{l}\text { GFR } \\
\left(\mathrm{ml} / \mathrm{min} / 1.73 \mathrm{~m}^{2}\right)\end{array}$ & $98.54 \pm 23.47$ & $86.77 \pm 20.80$ & $99.07 \pm 4.58$ & $<0.01$ & 0.02 & 0,41 & $<0.01$ \\
\hline Adropin, $\mathrm{ng} / \mathrm{ml}$ & $1.48 \pm 0.66$ & $2.08 \pm 0.75$ & $4.90 \pm 0.58$ & $<0.01$ & $<0.01$ & $<0.01$ & $<0.01$ \\
\hline IL-6, pg/ml & $8.87 \pm 1.78$ & $9.0452 \pm 2.17$ & $4.23 \pm 1.41$ & $<0.01$ & 0.89 & $<0.01$ & $<0.01$ \\
\hline
\end{tabular}

Data presented as Mean \pm SD.

SBP - systolic blood pressure; DBP - diastolic blood pressure; BMI - body mass index; LVEF - left ventricular ejection fraction; HTN - hypertension; 2TDM - diabetes mellitus 2 type; CIMT - carotid intima media thickness; TG triglycerides; TC - total cholesterol; LDLC - low-density cholesterol; HDHC - high density cholesterol; CIMT thickness intima-media; HTN - hypertension, GFR - glomerular filtration rate, .IL6 - interleukin 6.

$\mathrm{P}^{*}$ - P value between all groups;

$\mathrm{P} \alpha-\mathrm{P}$ value between CIMT $<0.9 \mathrm{~mm}$ and CIMT $\geq 0.9$; 
It is important to describe Spearmen rank analysis correlation between adropin levels and the rest of indices in the groups. Thus, as it displayed in Table 2, the adropin was significantly negatively correlated with CIMT in the group with normal values of CIMT $(r=-0.35$; $<<0.05)$, in the group with increased CIMT this correlation was significant, and had practically the same trend $(\mathrm{r}=-0.37$; $\mathrm{p}<0.05$ ). Serum adropin level had a negative statistical link with CIMT in 99 patients with HTN combined with 2 TDM $(-0.42 ; \mathrm{p}<0.05)$, with a more prominent pattern. During assessment of correlative link between CIMT and adropin in all 119 patients, we estimated a significant negative correlation $(-0.65, \mathrm{p}<0.05)$, that was the strongest compared to other groups.

Furthermore, correlation evaluation evidenced much more adropin's significant correlations among the whole enrolled patients (with SBP, DBP, BMI, CIMT, HbAc1, TC, TR, HDLC, LDLC, IL-6, IL-10) compared to separated groups (group 1, group 2). The group with CIMT $\geq 0.9 \mathrm{~mm}$ showed links with CIMT, HDLC, HTN (duration); the group with normal CIMT had adropin's link with CIMT, TC, GFR. The common group with combined pathology (group 1 and together) had adropin's correlation with CIMT, TC, IL-10, and GFR. In addition, the majority of these correlations had a converse character, but only HDLC association in the whole group $(n=119)$ was positive.

Consequently, there is an evidence that the link between CIMT and adropin in patients with absent manifestation of artery atherosclerosis is stronger than in patients with high indices of CIMT. Besides, the adropin level might be assessed as predictor of atherosclerosis in patients with the presence of combined pathology. Serum adropin level had a negative significant correlative link with the intensity of CIMT.

We did not find significant correlation between IL-6 and CIMT in all groups, besides the whole enrolled (all enrolled, $\mathrm{n}=119$ : $\mathrm{r}=0.463, \mathrm{p}<0.001$; all patients with HTN and 2TDM, $n=99$ : $r=0.077, p=0.4667$; group with CIMT $\geq 0.9 \mathrm{~mm}, \mathrm{n}=30$ : $\mathrm{r}=-0.060, \mathrm{p}=0,771$; group with CIMT $<0.9$ mm, $n=69: r=0,172, p=0.1662$ ).

We found a significant link between CIMT and BMI $(\mathrm{r}=0.552, \mathrm{p}<0.0001)$, and GFR $(\mathrm{r}=0.285, \mathrm{p}=0.021)$ in patients with CIMT $<0.9 \mathrm{~mm}$. In subjects with CIMT $\geq 0.9$ $\mathrm{mm}$, the CIMT correlated significantly with SBP ( $\mathrm{r}=0.514$, $\mathrm{p}=0.0037)$, with HTN duration $(\mathrm{r}=-0.488, \mathrm{p}=0.006)$, and with LVEF ( $r=-0.493, p=0.005)$, but the last two links were close to insignificant. In patients with combined HTN and 2TDM ( $\mathrm{n}=99)$, CIMT correlated with SBP, DBP,

Table 2. Correlation analyses between adropin level and the rest of parameters in different groups presented in the study.

\begin{tabular}{|c|c|c|c|c|}
\hline Parameter & $\begin{array}{l}\text { All enrolled } \\
\text { subjects } \\
\text { (including } \\
\text { control), } \mathrm{n}=119 \\
\end{array}$ & $\begin{array}{l}\text { Normal CIMT, } \\
\mathrm{N}=69\end{array}$ & $\begin{array}{l}\text { Increased CIMT, } \\
\mathrm{n}=30\end{array}$ & $\begin{array}{l}\text { Combined HTN with } \\
\text { 2TDM and obesity } \\
\text { (normal and increased } \\
\text { CIMT together) } n=99\end{array}$ \\
\hline Age, years & 0.04 & 0.12 & -0.19 & 0.03 \\
\hline Sex & 0.06 & 0.06 & 0.13 & 0.09 \\
\hline $\mathrm{SBP}, \mathrm{mmHg}$ & -0.50 & -0.05 & 0.21 & -0.15 \\
\hline DBP, mmHg & -0.37 & 0.17 & 0.31 & 0.08 \\
\hline 2TDM duration (years) & -0.01 & 0.07 & -0.20 & -0.01 \\
\hline LVEF, $(\%)$ & -0.05 & -0.10 & -0.06 & -0.12 \\
\hline CIMT, mm & -0.65 & -0.35 & -0.37 & -0.42 \\
\hline $\mathrm{BMI}, \mathrm{kg} / \mathrm{m}^{2}$ & -0.48 & -0.15 & 0.09 & -0.14 \\
\hline $\mathrm{HbAc1}(\%)$ & -0.38 & 0.07 & 0.02 & 0.07 \\
\hline $\mathrm{TC}, \mathrm{mmol} / \mathrm{l}$ & -0.47 & -0.29 & -0.05 & -0.27 \\
\hline $\mathrm{TR}, \mathrm{mmol} / \mathrm{l}$ & -0.42 & -0.21 & 0.18 & -0.15 \\
\hline $\mathrm{HDL}, \mathrm{mmol} / \mathrm{l}$ & $\mathbf{0 . 3 0}$ & 0.07 & -0.51 & -0.05 \\
\hline $\mathrm{LDL}, \mathrm{mmol} / \mathrm{l}$ & -0.20 & -0.08 & 0.19 & -0.03 \\
\hline IL-6, pg/ml & -0.48 & -0.13 & 0.12 & -0.08 \\
\hline HTN duration (years) & -0.12 & -0.02 & -0.48 & -0.12 \\
\hline GFR, $\mathrm{ml} / \mathrm{min} / 1.73 \mathrm{~m}^{2}$ & -0.03 & -0.25 & 0.06 & -0.23 \\
\hline Smoker & -0.08 & -0.11 & -0.23 & -0.11 \\
\hline
\end{tabular}

Note - Significant correlation marked with bold type. 
LVEF, BMI, GFR. When we analyzed the overall enrolled persons $(n=119)$, we established many relevant links of CIMT with other parameters, such as SBP, DBP, LVEF, BMI, TC, TR, HDL-C, IL-6. These results are displayed in Table 3 .

It worth to mention that the quantity of significant links is reducing in concordance with aggravation of the health status.

Figure 1 demonstrates the cut-off value of adropin at admission for prognosis increased intima-media thickness among studied subjects with combination of HTN, 2TDM and obesity, based on receiver-operating characteristic curve analysis, that was determined to be $1.80 \mathrm{ng} / \mathrm{ml}$, with a sensitivity of $76.67 \%$ and a specificity of $68.12 \%$ (area under the curve: 0.728 ; 95\% CI: $0.629-0.813$; $\mathrm{p}<0.001$ ).

\section{DISCUSSION}

The study revealed a reliable link between serum adropin level and intima-media thickness in patients with combined hypertension and type 2 diabetes mellitus and obesity. The nature of this connection was converse with moderate strength. Moreover, our data did not find a significant relationship between adropin and IL-6 in patients with combined HTN with 2TDM. On the other

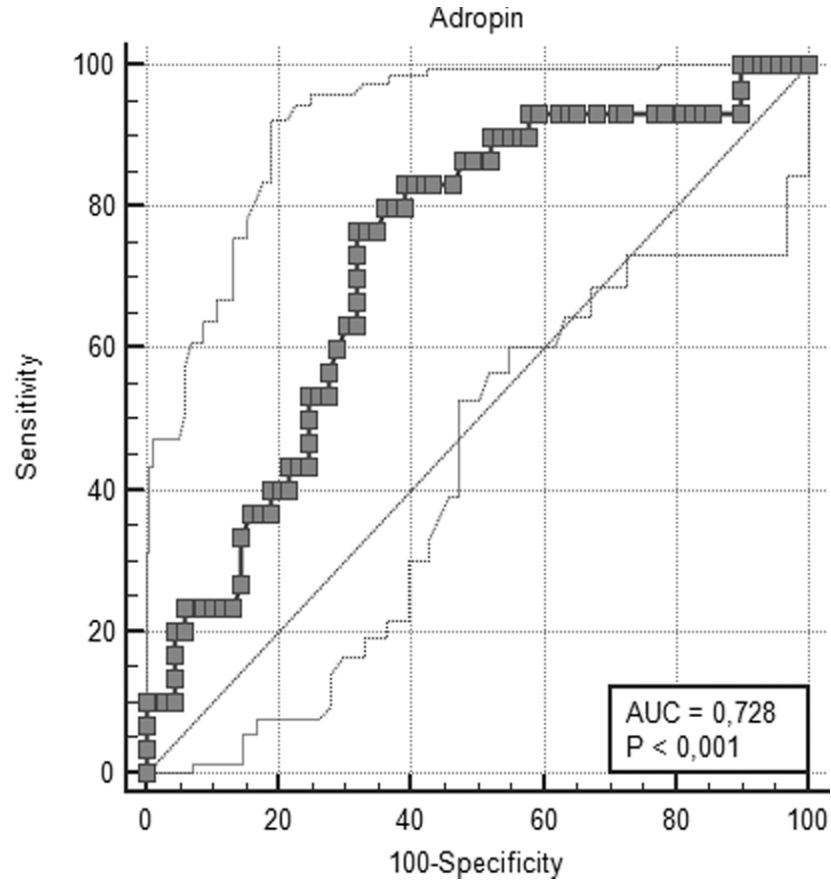

Figure 1. Receiver operational characteristic curve of adropin for prediction of atherosclerosis in patients with hypertension concomitant with type 2 diabetes mellitus and obesity.

Table 3. Spearmen rank order correlation between CIMT and other indices

\begin{tabular}{|c|c|c|c|c|}
\hline \multirow[b]{2}{*}{ Index } & \multicolumn{2}{|c|}{ All enrolled (patients with control, $n=119$ ) } & \multicolumn{2}{|c|}{ Patients with HTN, 2TDM, obesity ( $\mathrm{n}=99$ ) } \\
\hline & Spearman, $r$ & p-value & Spearman, $r$ & p-value \\
\hline $\mathrm{SBP}, \mathrm{mmHg}$ & 0.65 & $<0.01$ & 0.42 & $<0.01$ \\
\hline DBP, $\mathrm{mmHg}$ & 0.60 & $<0.01$ & 0.33 & $<0.01$ \\
\hline $\begin{array}{ll}2 \mathrm{TDM} & \text { (duration), } \\
\text { years } & \end{array}$ & 0.01 & 0.91 & 0.01 & 0.91 \\
\hline LVEF, \% & -0.25 & 0.01 & -0.30 & $<0.01$ \\
\hline BMI, $\mathrm{kg} / \mathrm{m}^{2}$ & 0.66 & $<0.01$ & 0.47 & $<0.01$ \\
\hline Adropin & -0.65 & $<0.01$ & -0.42 & $<0.01$ \\
\hline $\mathrm{HbAc1}, \%$ & 0.31 & $<0.01$ & -0.16 & 0.12 \\
\hline $\mathrm{TC}, \mathrm{mmol} / \mathrm{l}$ & 0.40 & $<0.01$ & 0.16 & 0.12 \\
\hline $\mathrm{TR}, \mathrm{mmol} / \mathrm{l}$ & 0.47 & $<0.01$ & 0.20 & 0.05 \\
\hline $\mathrm{HDLC}, \mathrm{mmol} / \mathrm{l}$ & -0.43 & $<0.01$ & -0.16 & 0.13 \\
\hline $\mathrm{LDLC}, \mathrm{mmol} / \mathrm{l}$ & 0.16 & 0.09 & -0.01 & 0.91 \\
\hline IL-6, pg/l & 0.46 & $<0.01$ & 0.08 & 0.47 \\
\hline HTN (duration), years & -0.13 & 0.19 & -0.13 & 0.19 \\
\hline $\mathrm{GFR}, \mathrm{ml} / \mathrm{min} / 1.73 \mathrm{~m}^{2}$ & 0.16 & 0.10 & 0.35 & $<0.01$ \\
\hline
\end{tabular}

Note - Significant correlation marked with bold type. 
side, there was a significant direct moderate correlation between IL-6 and CIMT $(\mathrm{r}=0.46 ; \mathrm{p}<0.0001)$, and a negative middle level link between IL- 6 and adropin ( $r=-$ $0.48, \mathrm{p}<0.05)$, if analyzing the total number of enrolled, including control.

Inflammation plays an important role in the development of atherosclerosis. There are some studies that demonstrated the link between IL-6 and atherosclerosis. Study Kamal Rasheed Mohammed et al. showed IL-6 levels increased significantly in patients with 2TDM, which is known to increase the inflammation and development of vascular disease and atherosclerosis (7). High IL-6 in the setting of type 2 diabetes is an independent predictor of cardiovascular events (8). The Italian study M. M. Ciccone et al. demonstrated that obstructive sleep apnea patients have increased levels of IL-6 and it might be a significant player in the progression of atherosclerosis (9). In addition, the study Lai C.L. proved that IL-6 levels can be considered as a marker for assessment the degree of coronary heart disease (CHD) and can represent the activity of atherosclerosis in CHD patients (10). Akihiko Kato et al. demonstrated that an elevation of IL-6 was associated with carotid atherosclerosis in hemodialysis patients (11). Wang et al study showed that the inflammation plays a significant role in the pathogenesis of atherosclerosis and IL-6 levels can be used to determine the stability of plaque (12). Our suggestion about the absence of a significant link between IL-6 and CIMT is that the investigated group had severe state and had concomitant diseases that suppressed inflammatory opportunities of organism. On the other hand, if we analyzed the overall enrolled subjects, including control, we found direct relevant IL-6 association with CIMT, which is in accordance with the above-mentioned studies.

It should be noted that the obtained data on the relationship between adropin and atherosclerosis are entirely correlated with the data of a number of studies, for example, with the results of Demircelik B. et al (13). However, they had patients with late saphenous vein graft occlusion but not HTN combined 2TDM, which distinguishes our studies. Their study found a decreased serum adropin level in patients with late saphenous vein graft occlusion. Ertem A. G. et al. on a group of patients with NSTEMI carried out the investigation, showed adropin's link with atherosclerosis. It resulted in a state that adropin plays a role in development of atherosclerotic burden in NSTEMI patients (14). Therewith, Çelik et al. (15) demonstrated that lower serum adropin levels are associated with cardiac syndrome X (CSX). Endothelial dysfunction has also play role in the pathogenesis of CSX, according to these data. Çelik et al. demonstrated that lower serum adropin levels are associated with CSX.
All these findings suggest that the interaction of atherosclerosis with adorpin is due to the adropin's influence on the endothelial function. Moreover, this correlated with the Lovren F. study (16). Moreover, another study said that adropin could be considered as a novel marker for endothelial dysfunction evaluation (17).

Atherosclerosis is associated with the presence of hypertension itself and the presence of diabetes mellitus, which in themselves affect its development. Another study reported about the link between obesity and a low level of adropin, but the absence of adropin's association with blood pressure (18). In our study, we had the same absence of significant correlation between adropin and blood pressure (BP) in HTN concomitant with 2TDM and obesity, but as for overall subjects (including control) it was significant. Other investigators showed the association of adropin with atherosclerosis and with diabetes mellitus (4). Wenchao $\mathrm{Hu}$ showed low serum adropin's correlation with risk of developing T2DM (19).

In our study, the difficulty was to separate the effect of hypertension from the effect of diabetes on the progression of atherosclerosis. At the same time, we can confirm the presence of the effect of a low adropin level on the development of enlargement CIMT. And this influence is present in a whole group of patients with a combined pathology, but the greater the severity of atherosclerosis is, this effect becomes smaller. We suggest that this may be due to the growth of adaptive mechanisms as the progression of atherosclerosis in such a severe category of patients that was presented in our study.

From our point of view, the effect of adropin on the progression of atherosclerosis is realized through the influence of adropin on the endothelial function. And this is confirmed by the Gu's X. data, that found a converse correlation between adropin and ET-1 (20).

At the same time, we also assume the adropin involvement in the inflammatory process during atherosclerosis development. We assert in our study a direct coherence of IL-6 with the CIMT, but only if we analyze overall subjects, including control. In case of patients with disease (combination of HTN, 2TDM and obesity) examination there were not significant links among IL-6 with CIMT, and IL-6 with adropin.

The limitation of our study was that it was crosssectional and that the number of patients was limited.

We assume that the data of this study can be extrapolated only to a group of patients with hypertension combined with diabetes mellitus 2 type with obesity. A study of the association of adropin with atherosclerosis in other groups of patients requires additional research.

In conclusion, a reduced serum adropin level showed significant association with intima media thickness in patients with HTN combined with 2TDM and obesity. 
Adropin deficiency is possibly an independent risk factor for the development of atherosclerosis. At last, the converse link between serum adropin level and CIMT evidences that adropin conceivably supply an antiatherosclerotic effect.

\section{REFERENCES}

1. Schneider AL, Kalyani RR, Golden S, et al. Diabetes and prediabetes and risk of hospitalization: the atherosclerosis risk in communities (ARIC) study. Diabetes Care 2016; 39:772-9.

2. Horr S, Nissen S. Managing hypertension in type 2 diabetes mellitus. Best Pract Res Clin Endocrinol Metab 2016; 30:445-54.

3. Niepolski L, Grzegorzewska AE. Salusins and adropin: new peptides potentially involved in lipid metabolism and atherosclerosis. Adv Med Sci 2016; 61:282-7.

4. Wu L, Fang J, Chen L, et al. Low serum adropin is associated with coronary atherosclerosis in type 2 diabetic and non-diabetic patients. Clin Chem Lab Med 2014; 52:751-8.

5. Kumar KG, Trevaskis JL, Lam DD, et al. Identification of adropin as a secreted factor linking dietary macronutrient intake with energy homeostasis and lipid metabolism. Cell Metab 2008; 8:468-81.

6. Simova I. Intima-media thickness: appropriate evaluation and proper measurement, described. EJournal of Cardiology Practice 2015; 13:21.

7. Mohammed Kamal Rasheed, Manal Kamal Rasheed, Halla GM. Interleukin -6 and high-sensitivity Creactive protein correlation in atherosclerosis in Iraqi type 2 diabetic patients. IOSR Journal of Dental and Medical Sciences 2013; 10:66-73.

8. Lowe G, Woodward M, Hillis G, et al. Circulating inflammatory markers and the risk of vascular complications and mortality in people with type 2 diabetes and cardiovascular disease or risk factors: the ADVANCE study. Diabetes 2014; 63:1115-23.

9. Ciccone MM, Scicchitano P, Zito A, et al. Correlation between inflammatory markers of atherosclerosis and carotid intima-media thickness in obstructive sleep apnea. Molecules 2014; 19:1651-62.
10. Lai CL, Ji YR, Liu XH, Xing JP, Zhao JQ. Relationship between coronary atherosclerosis plaque characteristics and high sensitivity C-reactive proteins, interleukin-6. Chin Med J (Engl) 2011; 124: 2452-6.

11. Kato A, Odamaki M, Takita T, Maruyama Y, Kumagai $\mathrm{H}$, Hishida A. Association between interleukin-6 and carotid atherosclerosis in hemodialysis patients. Kidney Int 2002; 61:1143-52.

12. Wang XH, Liu SQ, Wang YL, Jin Y. Correlation of serum high-sensitivity C-reactive protein and interleukin-6 in patients with acute coronary syndrome. Genet Mol Res 2014; 13:4260-6.

13. Demircelik B, Cakmak M, Nazli Y, et al. Adropin: a new marker for predicting late saphenous vein graft disease after coronary artery bypass grafting. Clin Invest Med 2014; 37:E338-44.

14. Ertem AG, Ünal S, Efe TH, et al. Association between serum adropin level and burden of coronary artery disease in patients with non-ST elevation myocardial infarction. Anatol J Cardiol 2017; 17:119-24.

15. Celik A, Balin M, Kobat MA, et al. Deficiency of a new protein associated with cardiac syndrome $\mathrm{X}$; called adropin. Cardiovasc Ther 2013; 31:174-8.

16. Lovren F, Pan Y, Quan A, et al. Adropin is a novel regulator of endothelial function. Circulation 2010; 122:S185-92.

17. Topuz M, Celik A, Aslantas T, Demir AK, Aydin S, Aydin S. Plasma adropin levels predict endothelial dysfunction like flow-mediated dilatation in patients with type 2 diabetes mellitus. J Investig Med 2013; 61:1161-4.

18. Altincik A, Sayin O. Evaluation of the relationship between serum adropin levels and blood pressure in obese children. J Pediatr Endocr Met 2015; 28:1095100.

19. Hu W, Chen L. Association of serum adropin concentrations with diabetic nephropathy. Mediat Inflamm 2016; Article ID 6038261.

20. Gu X, Li H, Zhu X, et al. Inverse correlation between plasma adropin and ET-1 levels in essential hypertension: a cross-sectional study. Medicine (Baltimore) 2015; 94:e1712. 